\title{
Liquid hot water treatment of rice straw enhances anaerobic degradation and inhibits methane production during in vitro ruminal fermentation
}

\author{
Xiu Min Zhang, ${ }^{1,2}$ Min Wang, ${ }^{1,2 *} \dagger \odot$ Qiang Yu, ${ }^{3 *} \ddagger$ Zhi Yuan Ma, ${ }^{1}$ Karen A. Beauchemin,,${ }^{4} \odot$ Rong Wang, ${ }^{1}$ \\ Jiang Nan Wen, ${ }^{1}$ Bernard A. Lukuyu, ${ }^{5}{ }^{\infty}$ and Zhi Liang Tan ${ }^{1,2}$ \\ ${ }^{1}$ Key Laboratory for Agro-Ecological Processes in Subtropical Region, Hunan Research Center of Livestock and Poultry Sciences, \\ South Central Experimental Station of Animal Nutrition and Feed Science in the Ministry of Agriculture, Institute of Subtropical Agriculture, \\ Chinese Academy of Sciences, Changsha, Hunan 410125, China \\ ${ }^{2}$ Hunan Co-Innovation Center of Animal Production Safety, Changsha, Hunan 410128, China \\ ${ }^{3}$ Guangzhou Institute of Energy Conversion, Chinese Academy of Sciences, CAS Key Laboratory of Renewable Energy, \\ Guangdong Provincial Key Laboratory of New and Renewable Energy Research and Development, Guangzhou, 510640, China \\ ${ }^{4}$ Agriculture and Agri-Food Canada, Lethbridge Research and Development Centre, Lethbridge, Alberta T1J 4B1, Canada \\ ${ }^{5}$ International Livestock Research Institute, Nairobi 00100, Kenya
}

\section{ABSTRACT}

Liquid hot water (LHW) treatment can be used to disrupt the fiber structure of rice straw. This in vitro ruminal batch culture study investigated the effect of LHW treatment on feed degradation, methane $\left(\mathrm{CH}_{4}\right)$ production, and microbial populations. Rice straw was treated by LHW, and in vitro ruminal fermentation was performed using an automatic system with $72 \mathrm{~h}$ of incubation. Scanning electron microscopy showed that LHW treatment disrupted the physical structure of rice straw. Liquid hot water treatment decreased neutral detergent fiber and hemicellulose contents of the rice straw and increased neutral detergent solubles, watersoluble carbohydrates, and arabinose contents. Liquid hot water treatment increased dry matter degradation and volatile fatty acid concentration and decreased the acetate:propionate ratio, $\mathrm{CH}_{4}$ production, hydrogen accumulation, neutral detergent fiber degradation, and populations of protozoa, fungi, and cellulolytic bacteria. In summary, LHW treatment disrupted the cellulose-hemicellulose-lignin structure matrix of rice straw, leading to increased substrate degradability and decreased $\mathrm{CH}_{4}$ production. Therefore, the LHW treatment is a potential strategy to improve the nutritive value of forage such as rice straw and decrease the $\mathrm{CH}_{4}$ emissions in ruminants.

Key words: liquid hot water, rumen fermentation, degradation, methane

Received May 3, 2019

Accepted January 1, 2020.

*Corresponding authors: mwang@isa.ac.cn and yuqiang@ms.giec.ac cn

$\dagger$ Present address: Institute of Subtropical Agriculture, The Chinese Academy of Sciences, Changsha 410125, China.

$\ddagger$ Present address: Guangzhou Institute of Energy Conversion, Chinese Academy of Sciences, Guangzhou 510640, China.

\section{INTRODUCTION}

Rice straw is one of the most abundant crop residues in the world, especially in China and Southeast Asia, and farmers use rice straw as the main roughage source for ruminants due to its abundant production and low cost. However, the recalcitrant cellulose-hemicelluloselignin structure of rice straw protects the biomass from attack by enzymes and microorganisms (Yu et al., 2016), thus resulting in low degradation in ruminal fermentation. Low degradation rates in the rumen decrease passage rate, leading to limited DMI (Colucci et al., 1982; Krizsan et al., 2010). Improving the degradation of rice straw would help to not only increase the use of this abundant agricultural by-product but also relieve the shortage of high-quality forage for ruminants.

Thermal treatment can effectively destroy the lignocellulosic structure of crop straws (Adesogan et al., 2019). For example, steam treatment works by applying high-pressure steam to break some bonds between lignin and hemicellulose and to hydrolyze some polysaccharides, which helps to increase ruminal degradability (Rai and Mudgal, 1996; Zhao et al., 2018). Liquid hot water (LHW) treatment uses pressure (above the saturated vapor pressure) to maintain water in a liquid state at elevated temperatures so that the water can act as both solvent and catalyst, thereby destroying the cell wall matrix and increasing the probability of cellulose getting hydrolyzed (Li et al., 2017). Compared with steam treatment, LHW treatment keeps the water at liquid state and thus can result in a greater amount of solubilized products (Bobleter, 1994). This process may help reduce undesirable degradation products such as furfural and the condensation and precipitation of lignin compounds (Hendriks and Zeeman, 2009). Previous studies have used LHW treatment as a biomassto-biofuel technology (Li et al., 2013; López González 
et al., 2014; Jiang et al., 2015). To our knowledge, the potential of LHW treatment to improve the nutritional value of crop residues for ruminants has not yet been explored.

Rumen fermentation produces methane $\left(\mathrm{CH}_{4}\right)$, which is an important greenhouse gas contributing to climate change (Beauchemin, 2009). If pretreatment of rice straw with LHW destroys the cell wall matrix and releases sugars, thereby increasing substrate degradation with enhanced propionate production by ruminal microbes, ruminal methanogenesis may decrease (Janssen, 2010). Furthermore, some compounds produced during LHW treatment, such as soluble lignin compounds, furfural, and hydroxymethylfurfural, are inhibitory or toxic to the growth of methanogens (Hendriks and Zeeman, 2009), which may lead to inhibition of methanogenesis.

We hypothesized that LHW treatment would destroy the cellulose-hemicellulose-lignin structure of rice straw and improve its anaerobic degradation and decrease methanogenesis. To test this hypothesis, rice straw was treated with LHW, dried, and incubated in vitro with buffered rumen inoculum for $72 \mathrm{~h}$.

\section{MATERIALS AND METHODS}

All animal procedures used in this study were reviewed and approved by the Animal Care Committee, Institute of Subtropical Agriculture, the Chinese Academy of Sciences, Changsha, China (ISA TAN201705).

\section{Experimental Design}

The experiment was a completely randomized block design (3 runs used as blocking factor with 2 replicates within each block) with 2 treatments (control or LHW).

\section{Substrate and Treatment}

Rice straw was collected from a commercial farm in Hunan province, China. Whole-plant mature rice was thrashed to remove the grain, and the straw was sun cured. The procedure used for the LHW treatment has been described by $\mathrm{Yu}$ et al. (2013). Briefly, $40 \mathrm{~g}$ of rice straw with 1-cm length was put into a 1-L stainless steel reactor with $200 \mathrm{~mL}$ of water. The reactor was sealed and heated to reach a temperature of $180^{\circ} \mathrm{C}$ under saturated vapor pressure for $10 \mathrm{~min}$ with a magnetic agitator operating at $500 \mathrm{rpm}$. Solid residue and liquid were collected and mixed together at the end of the reaction and oven-dried at $30^{\circ} \mathrm{C}$ for $4 \mathrm{~d}$ until constant weight. The dried material after LHW treatment and control straw were ground to pass through a 0.4-mm sieve (WJX-100, Yuanwo Company, Shanghai,
China) and stored in a desiccator at room temperature for subsequent measurement of chemical composition and in vitro ruminal incubation.

\section{In Vitro Incubation and Sampling Procedures}

Mixed rumen fluid from 3 healthy, ruminally cannulated adult Xiangdong black goats (average BW 25 $\pm 2.0 \mathrm{~kg}$ ) was used to prepare the inoculum for the in vitro batch culture fermentation. Goats were fed a TMR containing $500 \mathrm{~g} / \mathrm{kg}$ rice straw and $500 \mathrm{~g} / \mathrm{kg}$ concentrate (554 g of corn grain, $198 \mathrm{~g}$ of wheat bran, 185 $\mathrm{g}$ of soybean meal, $30 \mathrm{~g}$ of soybean oil, $12 \mathrm{~g}$ of calcium carbonate, $11 \mathrm{~g}$ of sodium chloride, and $10 \mathrm{~g}$ of premix with vitamins and microelements per kilogram of DM) offered twice per day at 0800 and $1800 \mathrm{~h}$.

Rumen contents were collected before the morning feeding. Rumen fluid was prepared by filtering the whole rumen contents through 4 layers of sterile cheesecloth into a prewarmed insulated bottle. The buffered rumen inoculum was obtained by mixing rumen fluid with artificial saliva (Menke et al., 1979) at a ratio of 1 to 4 (vol/vol). About $1.2 \mathrm{~g}$ of substrate was weighed into each $135-\mathrm{mL}$ serum bottle in duplicate, and 60 $\mathrm{mL}$ of buffered rumen inoculum was added under a steam of $\mathrm{CO}_{2}$. Bottles were immediately placed into the automatic incubation system described by Wang et al. (2016a), with venting pressure set at $10.0 \mathrm{kPa}$. Released gas automatically went into a gas chromatograph (Agilent 7890 A, Agilent Inc., Palo Alto, CA) for measuring $\mathrm{CH}_{4}$ and hydrogen $\left(\mathrm{H}_{2}\right)$ concentrations (Wang et al., 2016a). The $\mathrm{CH}_{4}$ production and $\mathrm{H}_{2}$ accumulation were calculated using the method described by Wang et al. (2013).

The length of incubation was set at $72 \mathrm{~h}$ based on our previous study with rice straw (Zhang et al., 2018). Rice straw is a fibrous substrate and degraded very slowly during in vitro ruminal fermentation; therefore, a relatively long incubation time was used. About 2 $\mathrm{mL}$ of liquid without visible particles was collected from each bottle and centrifuged at $15,000 \times g$ for 10 min at $4^{\circ} \mathrm{C}$. The supernatant $(1.5 \mathrm{~mL})$ was acidified using $0.15 \mathrm{~mL}$ of $25 \%$ (wt/vol) metaphosphoric acid and stored at $-20^{\circ} \mathrm{C}$ for analysis of VFA and ammonia. Samples for microbial analyses $(1 \mathrm{~mL} \times 3$ replications $)$ were collected after intense shaking of the bottle to ensure that representative portions of liquid and particle fractions were included. Microbial samples were immediately frozen in liquid $\mathrm{N}_{2}$ and stored at $-80^{\circ} \mathrm{C}$ until DNA extraction. After sampling for VFA and microbes, the $\mathrm{pH}$ was measured immediately with a portable pH meter (Starter 300; Ohaus Instruments Co. Ltd., Shanghai, China). Solid residues were filtered 
into preweighed Gooch filter crucibles, dried at $105^{\circ} \mathrm{C}$ to constant weight, and weighed to determine degradation of incubated substrates and NDF.

\section{Analytical Methods}

Scanning electron microscopy images of control and LHW-treated rice straw were obtained by field emission scanning electron microscopy (model SU8010, Hitachi, Tokyo, Japan) according to the manufacturer's instructions. Briefly, samples were carefully chosen from the same site of the stem and coated with gold before scanning. All scanning electron microscopy images were magnified 1,000 times.

The rice straw samples were analyzed in triplicate for DM (method 930.15), total N (method 970.22; CP $=\mathrm{N} \times 6.25)$, and crude fat (ether extraction, method 920.39) according to published methodologies (AOAC International, 2005). The NDF, ADF, and ADL contents were assayed according to the method of Van Soest et al. (1991) and expressed as inclusive of residual ash. A heat-stable $\alpha$-amylase was added in the NDF analysis. The water-soluble carbohydrate (WSC) fraction was measured using the anthrone method (Yemm and Willis, 1954). Monosaccharides and furfural were analyzed according to the standard laboratory analytical procedures for biomass analysis provided by the US National Renewable Energy Laboratory as described by $\mathrm{Yu}$ et al. (2010). Neutral-detergent solubles (NDS) content was calculated as by Van Soest and Robertson (1976):

$$
\operatorname{NDS}(\mathrm{g} / \mathrm{kg} \text { of DM) }=1,000-\mathrm{NDF}(\mathrm{g} / \mathrm{kg} \text { of DM }) \text {. }
$$

Hemicellulose was calculated as

$$
\begin{gathered}
\text { hemicellulose }(\mathrm{g} / \mathrm{kg} \text { of } \mathrm{DM})= \\
\mathrm{NDF}-\mathrm{ADF}(\mathrm{g} / \mathrm{kg} \text { of } \mathrm{DM})
\end{gathered}
$$

The NFC content was calculated as

$$
\begin{gathered}
\text { NFC }(\mathrm{g} / \mathrm{kg} \text { of } \mathrm{DM})= \\
1,000-(\mathrm{NDF}+\mathrm{CP}+\text { ether extract })(\mathrm{g} / \mathrm{kg} \text { of } \mathrm{DM}),
\end{gathered}
$$

with the ash included in the NDF. In vitro NDF degradation (NDFD) was calculated as by Zhang et al. (2018):

$$
\begin{gathered}
\operatorname{NDFD}(\mathrm{g} / \mathrm{kg})= \\
{\left[1-\left(\mathrm{W}_{2} \times \mathrm{NDF}_{2}\right) /\left(\mathrm{W}_{1} \times \mathrm{NDF}_{1}\right)\right] \times 1,000}
\end{gathered}
$$

where $\mathrm{NDF}_{1}$ is NDF content in the substrate before incubation, $\mathrm{NDF}_{2}$ is $\mathrm{NDF}$ content in the residue after $72 \mathrm{~h}$ of incubation, $\mathrm{W}_{1}$ is DM weight of substrate before incubation, and $\mathrm{W}_{2}$ is DM weight of residue after $72 \mathrm{~h}$ of incubation.

The VFA concentration was measured according to the procedure described by Wang et al. (2014) using a gas chromatograph (Agilent 7890 A, Agilent Inc.). Ammonia concentration was measured colorimetrically according to Chaney and Marbach (1962).

The DNA was extracted according to the protocol for pathogen detection in stool using an EZNA Stool DNA kit (Omega Bio-Tek, Norcross, GA). The protozoa, fungi, bacteria, and methanogen were examined in the present study, and major groups of fibrolytic bacteria (i.e., Fibrobacter succinogenes, Ruminococcus flavefaciens, and Ruminococcus albus; Wang and McAllister, 2002) and predominant methanogens (i.e., Methanobrevibacter and Methanomicrobium; Morgavi et al., 2010) were also quantified. Quantitative realtime PCR (qPCR) was performed according to the procedure described by Jiao et al. (2014). Forward and reverse primers selected from the literature for $\mathrm{qPCR}$ groups are shown in Table 1. A standard curve was generated using plasmid DNA containing the exact $16 \mathrm{~S} / 18 \mathrm{~S}$ rRNA gene inserts, and the standard curve met the following requirements: $\mathrm{R}^{2}>0.99,90 \%<\mathrm{E}$ $<120 \%$. The qPCR assay was performed on a LightCycler 480 (Roche Molecular Systems Inc., Pleasanton, CA) with a sample volume of $10 \mu \mathrm{L}$ that contained 5 $\mu \mathrm{L}$ of SYBR Green Mix (Takara Inc., Dalian, China), $1 \mu \mathrm{L}$ of genomic DNA $(10 \mathrm{ng} / \mu \mathrm{L}), 0.25 \mu \mathrm{L}$ of each primer, and $3.5 \mu \mathrm{L}$ of double-distilled $\mathrm{H}_{2} \mathrm{O}$.

\section{Data Analysis}

Net hydrogen production $\left(\mathbf{R}_{\mathrm{NH} 2}\right)$ was calculated based on VFA production using the equations described by Wang et al. (2014) as follows:

$$
\begin{array}{r}
\mathrm{R}_{\mathrm{NH} 2}=[2(\text { acetate }+ \text { butyrate }+ \text { isobutyrate }) \\
-(\text { propionate }+ \text { valerate }+ \text { isovalerate })] / \mathrm{VFA} .
\end{array}
$$

Total gas production over the 72 -h incubation was estimated from the cumulative pressure in the headspace of each bottle over time. Methane and $\mathrm{H}_{2}$ gas concentrations were measured each time that gas was automatically vented from each bottle. The fractional rates of gas production or $\mathrm{CH}_{4}$ production were estimated using the Nonlinear Regression Analysis Program (version 5.4; Sherrod, 1991) and calculated according to the equations described by Wang et al. (2011): 
Table 1. Primers for quantitative real-time assay

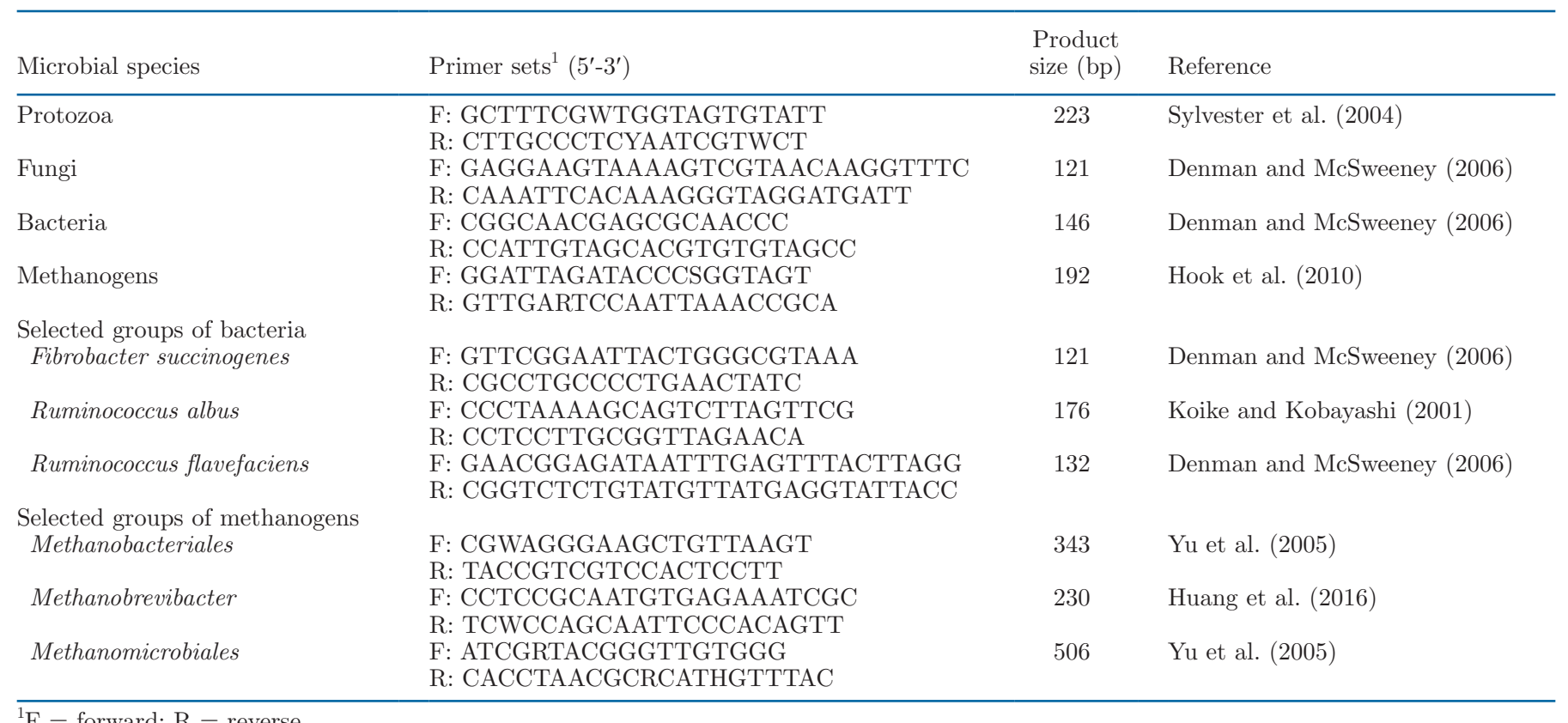

$$
G P_{t}=V f \times[1-\exp (-k t)] \times[1+\exp (b-k t)]
$$

where $G P_{t}$ is the accumulated gas production at time $t$, $V f$ is the final asymptotic gas production $(\mathrm{mmol} / \mathrm{g}), k$ is the fractional rate of gas production, and $b$ is the shape parameter. Then, the fractional rate of degradation at $0 \mathrm{~h}\left(\mathrm{FRD}_{0}\right)$ was calculated using the following equation:

$$
\mathrm{FRD}_{0}=k /[1-\exp (b)] .
$$

The kinetics of gaseous $\mathrm{H}_{2}\left(\mathbf{g H}_{2}\right)$ production $\left(V_{H}\right)$ were analyzed using the equations provided by Wang et al. (2013) and expressed as

$V_{H}=$

$\frac{V_{F H}\left\{1-\exp \left[-k_{H}\left(t-\operatorname{lag}_{H}\right)\right]\right\}\left\{1+c_{H} \exp \left[-\mu_{H}\left(t-\operatorname{lag}_{H}\right)\right]\right\}}{1+\exp \left[b_{H}-k_{H}\left(t-\log _{H}\right)\right]}$,

where $V F_{H}$ is the final asymptotic $\mathrm{gH}_{2}$ volume $(\mathrm{mL} / \mathrm{g})$, $b_{H}$ and $c_{H}$ are shape parameters of the $\mathrm{gH}_{2}$ curve without dimension, $k_{H}$ is the fractional rate of $\mathrm{gH}_{2}$ formation $(/ \mathrm{h}), \mu_{H}$ is the fractional rate of $\mathrm{gH}_{2}$ resolution $(/ \mathrm{h})$, and $\operatorname{lag}_{H}$ is discrete lag time $(\mathrm{h})$.

The results of the 2 bottles per treatment within each run were averaged and then analyzed using a mixed model with SPSS 19.0 (IBM Corp., Armonk, NY). The model included treatment $(\mathrm{n}=2)$ as fixed effect and run $(\mathrm{n}=3)$ as random effect. Statistical significance was considered at $P \leq 0.05$, with $0.05<P \leq 0.10$ considered as a tendency.

\section{RESULTS AND DISCUSSION}

\section{Physical Structure and Chemical Composition}

Liquid hot water treatment has been shown to be an effective means of destroying the structure of recalcitrant biomass, such as cotton stalk (Jiang et al., 2015) and the $\mathrm{C} 4$ perennial grass Miscanthus lutarioriparious (Li et al., 2013). The scanning electron microscopy images showed that LHW treatment destroyed the physical structure of rice straw (Figure 1), which is inconsistent with our previous findings for the LHW treatment of other biomass such as sugarcane bagasse (Yu et al., 2013). Water under high pressure and temperature penetrates into the biomass, breaking down the complex cell wall structure of cellulose-hemicellulose-lignin. In the present study, LHW treatment decreased hemicellulose content of rice straw $(-88.0 \%, P<0.001$; Table 2). Similarly, Li et al. (2013) reported that hemicellulose was substantially degraded in Miscanthus lutarioriparious treated with LHW. Jiang et al. (2015) reported a reduction in hemicellulose content in cotton stalk treated with LHW. The removal of hemicellulose from the cellulose-hemicellulose-lignin structure led to a reduction in NDF $(-44.8 \%, P<0.001)$ and ADF $(-30.7 \%, P<0.001)$ contents of rice straw after LHW treatment. Previous studies reported that LHW treatment degrades cellulose (Yu et al., 2010; Li et al., 2017) and thus decreases the degree of polymerization of cellulose ( $\mathrm{Li}$ et al., 2017). Liquid hot water treatment can also destroy the lignin structure by removing cinnamyl 


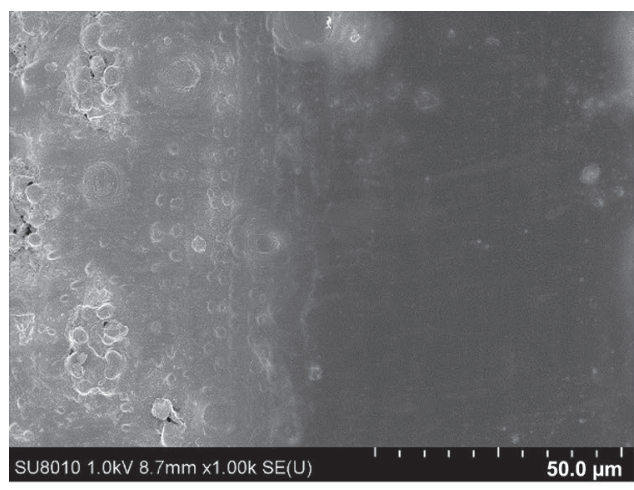

A

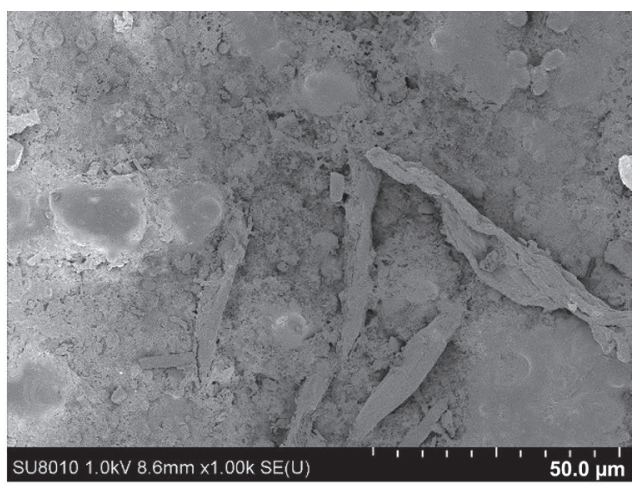

B

Figure 1. Scanning electron microscopy images of (A) untreated rice straw and (B) liquid hot water-treated rice straw.

alcohol and acetyl groups and decreasing $\beta-\mathrm{O}-4^{\prime}$ ether linkages ( $\mathrm{Li}$ et al., 2017). We also observed reduced ADL $(-19.0 \%, P=0.021)$ content in rice straw treated with LHW. Liquid hot water treatment can hydrolyze hemicellulose to simple sugars (Nitsos et al., 2016), leading to increased soluble components in biomass. In our study, LHW treatment also increased NDS $(+155 \%, P<0.001)$, WSC $(+107 \%, P<0.001)$, and NFC $(+202 \%, P<0.001)$ contents and NFC:NDF ratio (control vs. LHW $=0.22$ vs. 1.21).

Hemicellulose can be hydrolyzed into monosaccharides, mainly including arabinose, xylose, galactose, and rhamnose (Yu et al., 2016). In our study, LHW treatment increased arabinose $(+82.0 \%, P=0.015$; Table 1$)$ and rhamnose $(+479 \%, P<0.001)$ in rice straw. However, LHW treatment decreased galactose $(-30.9 \%, P=0.028)$, glucose $(-90.2 \%, P<0.001)$, xy- lose $(-31.6 \%, P=0.011)$, and fructose $(-96.6 \%, P<$ $0.001)$ contents and increased furfural content $(+102 \%$, $P=0.008)$. Lopez Gonzalez et al. (2014) reported that some monosaccharides, such as glucose, xylose, and fructose, can be dehydrated to 5-hydroxymethylfurfural, furfural, anhydrosaccharides, and organic acids by LHW treatment; this is consistent with the findings for LHW treatment of rice straw in the present study.

\section{In Vitro Ruminal Degradation and Total Gas Production}

The release of hemicellulose from the cell wall matrix increases NDS content, which may promote enzymatic hydrolysis and fermentation of the substrate. Neutraldetergent solubles include WSC, protein, and ether extract, which can be easily degraded by microorganisms

Table 2. Chemical composition change with liquid hot water (LHW) treatment

\begin{tabular}{lccrc}
\hline & \multicolumn{2}{c}{ Treatment } & & \\
\cline { 2 - 3 } Item & Control & LHW & SEM & P-value \\
\hline Nutrient components $(\mathrm{g} / \mathrm{kg})$ & & & & \\
Neutral detergent solubles & 224 & 572 & 77.2 & $<0.001$ \\
NDF & 776 & 428 & 77.2 & $<0.001$ \\
ADF & 584 & 405 & 40.3 & $<0.001$ \\
Water-soluble carbohydrates & 29.7 & 61.4 & 6.21 & $<0.001$ \\
Hemicellulose & 192 & 23.0 & 36.2 & $<0.001$ \\
ADL & 108 & 87.5 & 5.10 & 0.021 \\
CP & 39 & 40 & 2.3 & 0.12 \\
Ether extract & 14 & 15 & 0.6 & 0.29 \\
NFC & 171 & 517 & 78.1 & $<0.001$ \\
NFC:NDF ratio & 0.22 & 1.21 & 0.21 & $<0.001$ \\
Monosaccharides and furfural $(\mathrm{mg} / \mathrm{kg})$ & & & & \\
Arabinose & 472 & 859 & 85.5 & 0.015 \\
Galactose & 755 & 522 & 54.7 & 0.028 \\
Glucose & 10,961 & 1,075 & $2,187.5$ & $<0.001$ \\
Rhamnose & 8.4 & 48.6 & 8.80 & $<0.001$ \\
Xylose & 687 & 470 & 49.5 & 0.011 \\
Fructose & 2,632 & 88.9 & 569.9 & $<0.001$ \\
Furfural & 181 & 366 & 41.5 & 0.008 \\
\hline
\end{tabular}


Table 3. Effects of liquid hot water (LHW) treatment on biodegradation and parameters of gas production after $72 \mathrm{~h}$ of in vitro ruminal incubation

\begin{tabular}{lccccc}
\hline & \multicolumn{3}{c}{ Treatment } & & \\
\cline { 2 - 3 } Item $^{1}$ & Control & LHW & SEM & P-value \\
\hline Biodegradation (g/kg) & 605 & 742 & 7.6 & $<0.001$ \\
$\quad$ DM degradation & 581 & 466 & 17.2 & $<0.001$ \\
NDF degradation & & & & \\
Gas production & 206 & 229 & 3.8 & $<0.001$ \\
Total gas (mL/g of DM) & 207 & 228 & 4.9 & 0.039 \\
$\mathrm{~F}_{\mathrm{GP}}$ (mL/g of DM) & 0.06 & 0.09 & 0.001 & 0.008 \\
$\mathrm{k}_{\mathrm{GP}}$ & 0.87 & 1.01 & 0.059 & 0.19 \\
$\mathrm{~b}_{\mathrm{GP}}$ & 0.02 & 0.03 & 0.001 & $<0.001$ \\
$\mathrm{FRD}_{0}$ & & & & \\
\hline
\end{tabular}

${ }^{1} \mathrm{~F}_{\mathrm{GP}}=$ final asymptotic gas production; $\mathrm{k}_{\mathrm{GP}}=$ fractional rate of gas formation $(/ \mathrm{h}) ; \mathrm{b}_{\mathrm{GP}}=$ shape parameters of gas production curve without dimension; $\mathrm{FRD}_{0}=$ fractional rate of degradation at $0 \mathrm{~h}(/ \mathrm{h})$.

(Leiva et al., 2000). Zhang et al. (2018) found that rice straw with greater NDS content had greater in vitro DM degradation, gas production, and fractional rate of gas production. Getachew et al. (2004) reported that NFC in feedstuffs positively correlated with potential gas production. Forages with greater WSC content have greater in vitro DM degradation, degradation rate, and gas production (Amer et al., 2012). In the present study, LHW treatment increased DM degradation $(+22.6 \%, P$ $<0.001$; Table 3 ) of rice straw, which was accompanied by increases in gas production over the 72 -h incubation $(+11.2 \%, P<0.001)$, asymptotic gas production $(+10.1 \%, P=0.039)$, fractional rate of gas production $(+50 \%, P=0.008)$, and fractional rate of degradation at $0 \mathrm{~h}(+41.2 \%, P<0.001)$. Therefore, LHW treatment increased NDS, NFC, and WSC contents in rice straw, which helped to improve anaerobic rumen degradation. However, LHW treatment decreased fiber degradation, as indicated by a reduction in NDFD $(-19.8 \%, P<$
0.001). The increased NDS content by LHW treatment indicates solubilization of a large proportion of the more readily available portion of the NDF, which is the fiber fraction that can be degraded readily and thoroughly in the rumen (Hall et al., 1998). Consequently, after LHW treatment, the NDF residue had greater proportion of undegradable fiber (Robinson et al., 1987), leading to a reduction in NDF degradation.

\section{In Vitro Ruminal Fermentation Characteristics}

Ruminal VFA is mainly produced by fermentation of carbohydrates and thus can be affected by the components of carbohydrates in the incubated feedstuff. Getachew et al. (2004) reported that NFC content of feedstuffs was positively correlated with VFA concentration. Song et al. (2018) found that diets with high NFC:NDF ratio would increase VFA concentration. In our study, LHW treatment increased VFA concentration $(+14.2 \%, P<0.001$; Table 4$)$, which is consistent with the increased NFC content and NFC:NDF ratio. Increased VFA concentration was accompanied by decreased $\mathrm{pH}(P=0.007)$, which is consistent with the negative correlation between VFA and $\mathrm{pH}$ reported by Bramley et al. (2008). Furthermore, LHW treatment decreased ammonia concentration. Song et al. (2018) reported that greater NFC:NDF ratio helps increase ruminal ammonia utilization for microbial protein synthesis. Furthermore, it is possible that the increased NFC content due to LHW treatment helped synchronize energy and protein availability for growth of ruminal microbes, which would improve the use of ammonia $\mathrm{N}$ for microbial protein synthesis.

Changes in the structure of carbohydrates can also influence the profile of rumen fermentation. Song et al. (2018) reported that increasing NFC:NDF ratio favors

Table 4. Effects of liquid hot water (LHW) treatments on fermentation characteristics after $72 \mathrm{~h}$ of in vitro ruminal incubation

\begin{tabular}{lccccc}
\hline & \multicolumn{2}{c}{ Treatment } & & \\
\cline { 2 - 3 } Item & Control & LHW & SEM & P-value \\
\hline $\mathrm{pH}$ & 6.31 & 6.17 & 0.008 & 0.007 \\
Ammonia (mmol/L) & 11.0 & 9.62 & 0.161 & 0.008 \\
Total VFA (mmol/L) & 77.4 & 88.4 & 1.02 & $<0.001$ \\
Molar percentage of individual VFA (mol/100 mol of VFA) & & & & \\
$\quad$ Acetate & 70.0 & 57.5 & 0.24 & $<0.001$ \\
Propionate & 22.5 & 34.2 & 0.22 & $<0.001$ \\
Butyrate & 5.35 & 5.65 & 0.043 & 0.006 \\
Isobutyrate & 0.72 & 0.79 & 0.009 & 0.009 \\
Valerate & 0.69 & 0.70 & 0.085 & 0.19 \\
Isovalerate & 0.78 & 0.96 & 0.011 & 0.011 \\
Acetate:propionate ratio & 3.11 & 1.69 & 0.022 & $<0.001$ \\
$\mathrm{R}_{\mathrm{NH} 2}{ }^{\text {(mol/mol) }}$ & 1.28 & 0.92 & 0.012 & $<0.001$ \\
\hline
\end{tabular}

${ }^{1}$ Estimated net hydrogen production relative to the amount of total VFA produced. 
propionate production over acetate production. In our study, LHW treatment increased propionate molar percentage $(+52 \%, P<0.001)$ and decreased acetate molar percentage $(-17.9 \%, P<0.001)$ and acetate:propionate ratio $(-45.7 \%, P<0.001)$. These results are consistent with the reduction in NDF content and NDFD of rice straw when treated with LHW. Compared with fiber, ruminal NFC or WSC fermentation favors generating more propionate with less acetate production (Lee et al., 2003; Janssen, 2010). Such shifts of rumen fermentation result in changes in the efficiency of metabolic hydrogen incorporation into useful products (Wang et al., 2016b). Liquid hot water treatment decreased $\mathrm{R}_{\mathrm{NH} 2}$ $(-28.1 \%, P<0.001)$ relative to the amount of total VFA produced.

\section{Methane and $\mathrm{H}_{2}$ Production}

Molecular hydrogen is mainly produced during carbohydrate fermentation and utilized by the methanogens to produce $\mathrm{CH}_{4}$. The unused $\mathrm{H}_{2}$ may be transformed into a gaseous phase to form $\mathrm{gH}_{2}$, which is released to the atmosphere through venting. The amount of $\mathrm{gH}_{2}$ produced can be affected by many factors, such as rate of substrate degradation, rumen fermentation profile, and methanogenesis. In our study, LHW treatment increased fractional rate of $\mathrm{gH}_{2}$ formation $(+340 \%, P$ $<0.001)$ and decreased discrete lag time $(-71.0 \%, P$ $<0.001$ ), indicating that LHW treatment increased the rate of $\mathrm{gH}_{2}$ generation. These results are consistent with greater WSC content. However, a greater rate of $\mathrm{gH}_{2}$ generation did not lead to greater $\mathrm{gH}_{2}$ accumulation. Liquid hot water treatment decreased $\mathrm{gH}_{2}$ accumulation in terms of microliters per gram of DM $(-31.9 \%$, $P<0.001$; Table 5), microliters per gram of digestible $\mathrm{DM}(-44.4 \%, P<0.001)$, and final asymptotic $\mathrm{gH}_{2}$ accumulation $(-53.6 \%, P<0.001)$. The shift of rumen fermentation from acetate to propionate production with decreased $\mathrm{R}_{\mathrm{NH} 2}$ probably decreased $\mathrm{H}_{2}$ accumulation as expected.

As $\mathrm{H}_{2}$ is the major substrate for methanogenesis (Janssen, 2010), a reduction in $\mathrm{H}_{2}$ production can decrease $\mathrm{CH}_{4}$ production. Liquid hot water treatment decreased $\mathrm{CH}_{4}$ production, expressed as milliliters per gram of DM $(-14.8 \%, P<0.001)$, milliliters per gram of digestible DM $(-29.8 \%, P<0.001)$, and percent of total gas $(-16.5 \%, P=0.005)$, and asymptotic $\mathrm{CH}_{4}$ production $(-14.9 \%, P<0.001)$. However, LHW treatment did not decrease the fractional rate of $\mathrm{CH}_{4}$ production (expressed per hour). A further investigation of $\mathrm{CH}_{4}$ kinetics indicated that rate of $\mathrm{CH}_{4}$ production was faster at the initial stage of fermentation and decreased at the later stage of fermentation, resulting in a reduc-

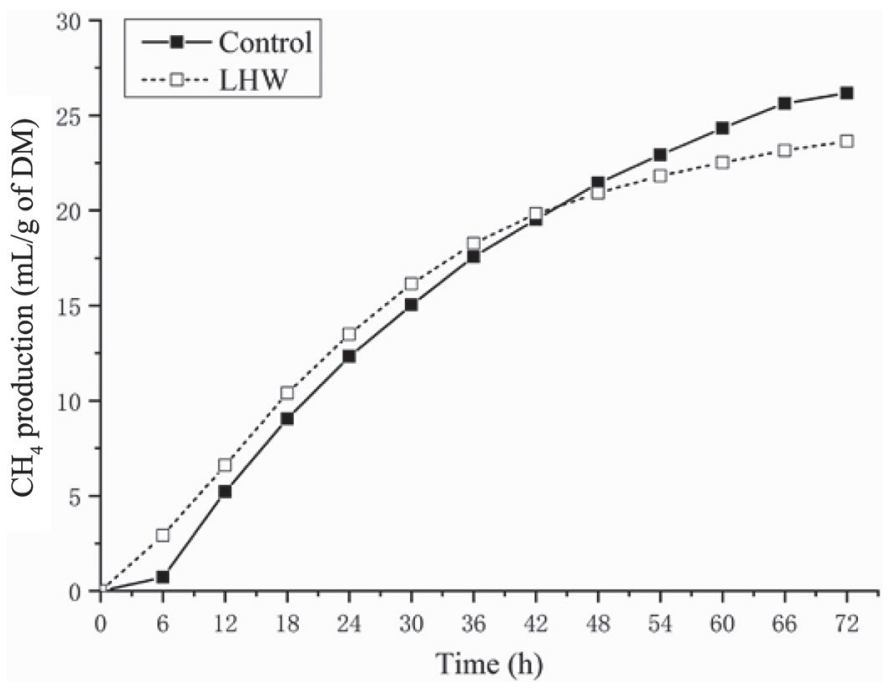

Figure 2. Methane $\left(\mathrm{CH}_{4}\right)$ production during $72 \mathrm{~h}$ of in vitro fermentation. $\mathrm{LHW}=$ liquid hot water treatment.

tion in $\mathrm{CH}_{4}$ production by LHW treatment compared with the control (Figure 2).

\section{Changes in Microbial Taxa}

Degradation of carbohydrates in the rumen is carried out by a consortium of bacteria, protozoa, and fungi. Fungi and bacteria contribute to about $80 \%$ of the degradation of plant cell walls, and protozoa contribute to the remaining 20\% (Wang and McAllister, 2002). Liquid hot water treatment decreased $18 \mathrm{~S}$ rRNA gene copies of protozoa $(P<0.001$; Table 6$)$, fungi $(P<0.001)$, and $16 \mathrm{~S}$ rRNA gene copies of dominant

Table 5. Effects of liquid hot water (LHW) treatment on parameters of methane $\left(\mathrm{CH}_{4}\right)$ and hydrogen $\left(\mathrm{H}_{2}\right)$ production after $72 \mathrm{~h}$ of in vitro ruminal incubation

\begin{tabular}{|c|c|c|c|c|}
\hline \multirow[b]{2}{*}{ Item $^{1}$} & \multicolumn{2}{|c|}{ Treatment } & \multirow[b]{2}{*}{ SEM } & \multirow[b]{2}{*}{$P$-value } \\
\hline & Control & LHW & & \\
\hline $\mathrm{CH}_{4}(\mathrm{~mL} / \mathrm{g}$ of $\mathrm{DM})$ & 25.9 & 22.5 & 0.51 & $<0.001$ \\
\hline $\mathrm{CH}_{4}(\mathrm{~mL} / \mathrm{g}$ of DDM $)$ & 43.1 & 30.2 & 1.02 & $<0.001$ \\
\hline $\mathrm{CH}_{4}$ (\% of total gas) & 13.9 & 11.6 & 0.17 & 0.005 \\
\hline $\mathrm{F}_{\mathrm{CH} 4}(\mathrm{~mL} / \mathrm{g}$ of $\mathrm{DM})$ & 26.1 & 22.3 & 0.26 & $<0.001$ \\
\hline $\mathrm{k}_{\mathrm{CH} 4}$ & 0.07 & 0.07 & 0.003 & 0.12 \\
\hline $\mathrm{gH}_{2}(\mu \mathrm{L} / \mathrm{g}$ of $\mathrm{DM})$ & 34.6 & 23.6 & 4.09 & $<0.001$ \\
\hline $\mathrm{gH}_{2}(\mu \mathrm{L} / \mathrm{g}$ of $\mathrm{DDM})$ & 57.6 & 32.0 & 7.06 & $<0.001$ \\
\hline $\mathrm{gH}_{2}$ (\% of total gas) & 0.02 & 0.01 & 0.003 & 0.006 \\
\hline $\mathrm{F}_{\mathrm{H}}(\mu \mathrm{L} / \mathrm{g}$ of $\mathrm{DM})$ & 50.2 & 23.3 & 7.42 & $<0.001$ \\
\hline $\mathrm{k}_{\mathrm{H}}$ & 0.05 & 0.22 & 0.03 & $<0.001$ \\
\hline $\operatorname{lag}_{\mathrm{H}}$ & 2.62 & 0.76 & 0.28 & $<0.001$ \\
\hline
\end{tabular}

${ }^{1} \mathrm{DDM}=$ digestible DM; $\mathrm{F}_{\mathrm{CH} 4}=$ final asymptotic $\mathrm{CH}_{4}$ production; $\mathrm{k}_{\mathrm{CH} 4}$ $=$ fractional rate of $\mathrm{CH}_{4}$ formation $(/ \mathrm{h}) ; \mathrm{gH}_{2}=$ gaseous $\mathrm{H}_{2} ; \mathrm{F}_{\mathrm{H}}=$ final asymptotic $\mathrm{gH}_{2}$ volume; $\mathrm{k}_{\mathrm{H}}=$ fractional rate of $\mathrm{gH}_{2}$ formation $(/ \mathrm{h})$; $\operatorname{lag}_{\mathrm{H}}=$ discrete lag time $(\mathrm{h})$. 
Table 6. Effects of liquid hot water (LHW) treatment on microbes $\left(\log _{10} / \mathrm{mL}\right)$ after $72 \mathrm{~h}$ of in vitro ruminal incubation

\begin{tabular}{|c|c|c|c|c|}
\hline \multirow[b]{2}{*}{ Item } & \multicolumn{2}{|c|}{ Treatment } & \multirow[b]{2}{*}{ SEM } & \multirow[b]{2}{*}{$P$-value } \\
\hline & Control & LHW & & \\
\hline Protozoa & 8.49 & 7.59 & 0.063 & $<0.001$ \\
\hline Fungi & 8.05 & 6.53 & 0.144 & $<0.001$ \\
\hline Bacteria & 10.42 & 10.25 & 0.051 & 0.058 \\
\hline Methanogens & 8.49 & 8.45 & 0.051 & 0.54 \\
\hline \multicolumn{5}{|l|}{ Selected bacteria } \\
\hline Fibrobacter succinogenes & 8.34 & 7.60 & 0.082 & $<0.001$ \\
\hline Ruminococcus albus & 6.74 & 5.98 & 0.073 & $<0.001$ \\
\hline Ruminococcus flavefaciens & 7.79 & 6.19 & 0.129 & 0.005 \\
\hline \multicolumn{5}{|l|}{ Selected methanogens } \\
\hline Methanobacteriales & 8.31 & 8.33 & 0.039 & 0.79 \\
\hline Methanobrevibacter & 8.20 & 8.18 & 0.061 & 0.83 \\
\hline Methanomicrobiales & 6.18 & 6.20 & 0.074 & 0.86 \\
\hline
\end{tabular}

cellulolytic bacteria, including $F$. succinogenes $(P<$ $0.001), R$. albus $(P<0.001)$, and $R$. flavefaciens $(P=$ 0.005 ), and tended to decrease $16 \mathrm{~S}$ rRNA gene copies of total bacteria $(P=0.058)$. The decreased populations of major cellulolytic microorganisms indicated that the NDF in the residue after LHW treatment was difficult to degrade. Furthermore, LHW treatment may have generated some degradation by-products (e.g., phenolic compounds, furfural, and hydroxymethylfurfural) that are toxic to bacteria (Hendriks and Zeeman, 2009). In addition, LHW treatment decreased $\mathrm{pH}$, which may also inhibit growth and activity of cellulolytic bacteria (Martin et al., 2010). Although greater NDS content of LHW-treated rice straw would be expected to increase the populations of some bacteria, the decreased populations of major cellulolytic bacteria could account for the lack of overall increase in the population of total bacteria.

Methane reduction can be achieved by diverting $\mathrm{H}_{2}$ away from methanogenesis or by inhibiting activity of methanogens to use $\mathrm{H}_{2}$ (Patra, 2012). In our study, the decreased $\mathrm{H}_{2}$ production and $\mathrm{pH}$ were probably the contributing factors that influenced ruminal methanogenesis. However, LHW treatment did not alter $16 \mathrm{~S}$ rRNA gene copies of total methanogens, Methanobacteriales, Methanobrevibacter, or Methanomicrobiales. Methanogens can grow and regulate expression of genes encoding for methanogenesis enzymes depending on the availability of rumen $\mathrm{H}_{2}$ concentration (Shima et al., 2002). Kim et al. (2004) also reported that the lower $\mathrm{pH}$ with LHW treatment could inhibit the ability of methanogens to use $\mathrm{H}_{2}$. Thus, it seems that the decreased $\mathrm{CH}_{4}$ production in LHW treatment was caused by an inhibition of methanogenesis activity rather than a direct effect on the methanogen population.

In summary, LHW treatment destroyed the resistant cellulose-hemicellulose-lignin structure of rice straw, de- creased hemicellulose and NDF contents, and increased NDS, NFC, and WSC contents. The increased NDS and NFC after LHW treatment promoted rumen fermentation with increased DM degradation and VFA production and shifted fermentation toward greater propionate production and less $\mathrm{CH}_{4}$ and $\mathrm{gH}_{2}$ accumulation. The residual fiber after LHW treatment was more indigestible, which likely led to the decreased $18 \mathrm{~S}$ rRNA gene copies of protozoa and fungi and 16S rRNA gene copies of predominant cellulolytic bacteria. Therefore, LHW treatment can be an alternative strategy to improve the degradation of rice straw and decrease $\mathrm{CH}_{4}$ production. A larger scale pilot study is warranted that examines the cost versus benefit of LHW treatment of crop residues for ruminants.

\section{ACKNOWLEDGMENTS}

This work was supported by National Natural Science Foundation of China (Beijing, Grant No. 31561143009 and 31922080), National Key Research and Development Program of China (Beijing, Grant No. 2016YFD0500504 and 2018YFD0501800), State Key Laboratory of Animal Nutrition (Beijing, Grant No. 2004DA125184F1705), China Agriculture Research System (Beijing, Grant No. CARS-36), Major Project of Hunan Province (Changsha, Grant No. 2017NK1020), Youth Innovation Promotion Association CAS (Changsha, Grant No. 2016327 and 2015289), CAS President's International Fellowship (Beijing, Grant No. 2018VBA0031), and Young Top-Notch Talent of Guangdong Province, China (Guangzhou, Grant No. 2016TQ03N647). The authors have stated that they have no conflicts of interest.

\section{REFERENCES}

Adesogan, A. T., K. G. Arriola, Y. Jiang, A. Oyebade, E. M. Paula, A. A. Pech-Cervantes, J. J. Romero, L. F. Ferraretto, and D. Vyas. 2019. Symposium review: Technologies for improving fiber utilization. J. Dairy Sci. 102:5726-5755. https://doi.org/10.3168/jds 2018-15334.

Amer, S., F. Hassanat, R. Berthiaume, P. Seguin, and A. F. Mustafa. 2012. Effects of water soluble carbohydrate content on ensiling characteristics, chemical composition and in vitro gas production of forage millet and forage sorghum silages. Anim. Feed Sci. Technol. 177:23-29. https://doi.org/10.1016/j.anifeedsci.2012.07.024.

AOAC International. 2005. Official Methods of Analysis. 18th ed. AOAC International, Gaithersburg, MD.

Beauchemin, K. 2009. Dietary mitigation of enteric methane from cattle. Perspect. Agric. Vet. Sci. Nutr. Nat. Resour. 4:35. https:// doi.org/10.1079/PAVSNNR20094035.

Bobleter, O. 1994. Hydrothermal degradation of polymers derived from plants. Prog. Polym. Sci. 19:797-841. https://doi.org/10 .1016/0079-6700(94)90033-7.

Bramley, E., I. J. Lean, W. J. Fulkerson, M. A. Stevenson, A. R. Rabiee, and N. D. Costa. 2008. The definition of acidosis in dairy herds predominantly fed on pasture and concentrates. J. Dairy Sci. 91:308-321. https://doi.org/10.3168/jds.2006-601. 
Chaney, A. L., and E. P. Marbach. 1962. Modified reagents for determination of urea and ammonia. Clin. Chem. 8:130-132.

Colucci, P. E., L. E. Chase, and P. J. Van Soest. 1982. Feed intake, apparent diet digestibility, and rate of particulate passage in dairy cattle. J. Dairy Sci. 65:1445-1456. https://doi.org/10.3168/jds .S0022-0302(82)82367-9.

Denman, S. E., and C. S. McSweeney. 2006. Development of a realtime PCR assay for monitoring anaerobic fungal and cellulolytic bacterial populations within the rumen. FEMS Microbiol. Ecol. 58:572-582. https://doi.org/10.1111/j.1574-6941.2006.00190.x.

Getachew, G., P. H. Robinson, E. J. DePeters, and S. J. Taylor. 2004 Relationships between chemical composition, dry matter degradation and in vitro gas production of several ruminant feeds. Anim. Feed Sci. Technol. 111:57-71. https://doi.org/10.1016/S0377 -8401(03)00217-7.

Hall, M. B., A. N. Pell, and L. E. Chase. 1998. Characteristics of neutral detergent-soluble fiber fermentation by mixed ruminal microbes. Anim. Feed Sci. Technol. 70:23-39. https://doi.org/10 .1016/S0377-8401(97)00068-0.

Hendriks, A. T., and G. Zeeman. 2009. Treatments to enhance the digestibility of lignocellulosic biomass. Bioresour. Technol. 100:1018. https://doi.org/10.1016/j.biortech.2008.05.027.

Hook, S. E., A. D. Wright, and B. W. McBride. 2010. Methanogens: Methane producers of the rumen and mitigation strategies. Archaea 2010:945785. https://doi.org/10.1155/2010/945785.

Huang, X. D., G. Martinez-Fernandez, J. Padmanabha, R. Long, S. E. Denman, and C. S. McSweeney. 2016. Methanogen diversity in indigenous and introduced ruminant species on the Tibetan plateau. Archaea 2016:5916067. https://doi.org/10.1155/2016/5916067.

Janssen, P. H. 2010. Influence of hydrogen on rumen methane formation and fermentation balances through microbial growth kinetics and fermentation thermodynamics. Anim. Feed Sci. Technol. 160:1-22. https://doi.org/10.1016/j.anifeedsci.2010.07.002.

Jiang, W., S. Chang, H. Li, P. Oleskowicz-Popiel, and J. Xu. 2015. Liquid hot water treatment on different parts of cotton stalk to facilitate ethanol production. Bioresour. Technol. 176:175-180. https://doi.org/10.1016/j.biortech.2014.11.023.

Jiao, J., P. Wang, Z. He, S. Tang, C. Zhou, X. Han, M. Wang, D. Wu, J. Kang, and Z. Tan. 2014. In vitro evaluation on neutral detergent fiber and cellulose digestion by post-ruminal microorganisms in goats. J. Sci. Food Agric. 94:1745-1752. https://doi.org/10.1002/ jsfa. 6485 .

Kim, I. S., M. H. Hwang, N. Jang, S. H. Hyun, and S. T. Lee. 2004. Effect of low $\mathrm{pH}$ on the activity of hydrogen utilizing methanogen in bio-hydrogen process. Int. J. Hydrogen Energy 29:1133-1140. https://doi.org/10.1016/j.ijhydene.2003.08.017.

Koike, S., and Y. Kobayashi. 2001. Development and use of competitive PCR assays for the rumen cellulolytic bacteria: Fibrobacter succinogenes, Ruminococcus albus and Ruminococcus flavefaciens. FEMS Microbiol. Lett. 204:361-366. https://doi.org/10.1111/j .1574-6968.2001.tb10911.x

Krizsan, S. J., S. Ahvenjärvi, and P. Huhtanen. 2010. A meta-analysis of passage rate estimated by rumen evacuation with cattle and evaluation of passage rate prediction models. J. Dairy Sci. 93:5890-5901. https://doi.org/10.3168/jds.2010-3457.

Lee, M. R. F., R. J. Merry, D. R. Davies, J. M. Moorby, M. O. Humphreys, M. K. Theodorou, J. C. MacRae, and N. D. Scollan. 2003. Effect of increasing availability of water-soluble carbohydrates on in vitro rumen fermentation. Anim. Feed Sci. Technol. 104:59-70. https://doi.org/10.1016/S0377-8401(02)00319-X.

Leiva, E., M. B. Hall, and H. H. Van Horn. 2000. Performance of dairy cattle fed citrus pulp or corn products as sources of neutral detergent-soluble carbohydrates. J. Dairy Sci. 83:2866-2875. https: //doi.org/10.3168/jds.S0022-0302(00)75187-3.

Li, H. Q., C. L. Li, T. Sang, and J. Xu. 2013. Treatment on Miscanthus lutarioriparious by liquid hot water for efficient ethanol production. Biotechnol. Biofuels 6:76. https://doi.org/10.1186/1754-6834 $-6-76$.

Li, M., S. Cao, X. Meng, M. Studer, C. E. Wyman, A. J. Ragauskas, and Y. Pu. 2017. The effect of liquid hot water treatment on the chemical-structural alteration and the reduced recalcitrance in poplar. Biotechnol. Biofuels 10:237. https://doi.org/10.1186/ s13068-017-0926-6.

Lopez Gonzalez, L. M., I. Pereda Reyes, J. Dewulf, J. Budde, M. Heiermann, and H. Vervaeren. 2014. Effect of liquid hot water pretreatment on sugarcane press mud methane yield. Bioresour. Technol. 169:284-290. https://doi.org/10.1016/j.biortech.2014.06.107.

Martin, C., D. P. Morgavi, and M. Doreau. 2010. Methane mitigation in ruminants: From microbe to the farm scale. Animal 4:351-365. https://doi.org/10.1017/S1751731109990620.

Menke, K. H., L. Raab, A. Salewski, H. Steingass, D. Fritz, and W. Schneider. 1979. The estimation of the digestibility and metabolizable energy content of ruminant feedingstuffs from the gas production when they are incubated with rumen liquor in vitro. J. Agric. Sci. 93:217-222. https://doi.org/10.1017/S0021859600086305.

Morgavi, D. P., E. Forano, C. Martin, and C. J. Newbold. 2010. Microbial ecosystem and methanogenesis in ruminants. Animal 4:10241036. https://doi.org/10.1017/S1751731110000546.

Nitsos, C. K., T. Choli-Papadopoulou, K. A. Matis, and K. S. Triantafyllidis. 2016. Optimization of hydrothermal treatment of hardwood and softwood lignocellulosic residues for selective hemicellulose recovery and improved cellulose enzymatic hydrolysis ACS Sustain. Chem. Eng. 4:4529-4544. https://doi.org/10.1021/ acssuschemeng.6b00535.

Patra, A. K. 2012. Enteric methane mitigation technologies for ruminant livestock: A synthesis of current research and future directions. Environ. Monit. Assess. 184:1929-1952. https://doi.org/10 .1007/s10661-011-2090-y.

Rai, S. N., and V. D. Mudgal. 1996. Effect of alkali and (or) steam treatment of wheat straw or cellulase augmented concentrate mixture on rumen fermentation in goats. Small Rumin. Res. 19:219225. https://doi.org/10.1016/0921-4488(95)00759-8.

Robinson, P. H., R. E. Brice, and I. M. Morrison. 1987. Effect of straw treatment and laboratory of incubation on degradation of neutral detergent residue in the rumen. Anim. Feed Sci. Technol. 18:75-82. https://doi.org/10.1016/0377-8401(87)90031-9.

Sherrod, P. H. 1991. NLREG: Nonlinear Regression Analysis Program. Phillip H. Sherrod, Brentwood, TN.

Shima, S., E. Warkentin, R. K. Thauer, and U. Ermler. 2002. Structure and function of enzymes involved in the methanogenic pathway utilizing carbon dioxide and molecular hydrogen. J. Biosci Bioeng. 93:519-530. https://doi.org/10.1016/s1389-1723(02)80232 -8 .

Song, S. D., G. J. Chen, C. H. Guo, K. Q. Rao, Y. H. Gao, Z. L. Peng, Z. F. Zhang, X. Bai, Y. Wang, B. X. Wang, Z. H. Chen, X. S. $\mathrm{Fu}$, and W. L. Zhu. 2018. Effects of exogenous fibrolytic enzyme supplementation to diets with different NFC/NDF ratios on the growth performance, nutrient digestibility and ruminal fermentation in Chinese domesticated black goats. Anim. Feed Sci. Technol. 236:170-177. https://doi.org/10.1016/j.anifeedsci.2017.12.008.

Sylvester, J. T., S. K. Karnati, Z. Yu, M. Morrison, and J. L. Firkins. 2004. Development of an assay to quantify rumen ciliate protozoal biomass in cows using real-time PCR. J. Nutr. 134:3378-3384. https://doi.org/10.1093/jn/134.12.3378.

Van Soest, P. J., and J. B. Robertson. 1976. Chemical and physical properties of dietary fibre. Pages 13-25 in Dietary Fibre: Proceedings of the Miles Symposium. W. W. Hawkins, ed. Nutrition Society of Canada, Halifax, NS, Canada.

Van Soest, P. J., J. B. Robertson, and B. A. Lewis. 1991. Methods for dietary fiber, neutral detergent fiber, and nonstarch polysaccharides in relation to animal nutrition. J. Dairy Sci. 74:3583-3597. https://doi.org/10.3168/jds.S0022-0302(91)78551-2.

Wang, M., P. H. Janssen, X. Z. Sun, S. Muetzel, M. Tavendale, Z. L. Tan, and D. Pacheco. 2013. A mathematical model to describe in vitro kinetics of $\mathrm{H}_{2}$ gas accumulation. Anim. Feed Sci. Technol. 184:1-16. https://doi.org/10.1016/j.anifeedsci.2013.05.002.

Wang, M., X. Z. Sun, P. H. Janssen, S. X. Tang, and Z. L. Tan. 2014. Responses of methane production and fermentation pathways to the increased dissolved hydrogen concentration generated by eight substrates in in vitro ruminal cultures. Anim. Feed Sci. Technol. 194:1-11. https://doi.org/10.1016/j.anifeedsci.2014.04.012. 
Wang, M., S. X. Tang, and Z. L. Tan. 2011. Modeling in vitro gas production kinetics: Derivation of Logistic-Exponential (LE) equations and comparison of models. Anim. Feed Sci. Technol. 165:137-150. https://doi.org/10.1016/j.anifeedsci.2010.09.016.

Wang, M., R. Wang, S. X. Tang, Z. L. Tan, C. S. Zhou, X. F. Han and J. H. Kang. 2016a. Comparisons of manual and automated incubation systems: Effects of venting procedures on in vitro ruminal fermentation. Livest. Sci. 184:41-45. https://doi.org/10.1016/ j.livsci.2015.12.002.

Wang, M., R. Wang, S. Yang, J. P. Deng, S. X. Tang, and Z. L. Tan. 2016b. Effects of three methane mitigation agents on parameters of kinetics of total and hydrogen gas production, ruminal fermentation and hydrogen balance using in vitro technique. Anim. Sci. J. 87:224-232. https://doi.org/10.1111/asj.12423.

Wang, Y., and T. A. McAllister. 2002. Rumen microbes, enzymes and feed digestion - A review. Asian-australas. J. Anim. Sci. 15:1659 1676. https://doi.org/10.5713/ajas.2002.1659.

Yemm, E. W., and A. J. Willis. 1954. The estimation of carbohydrates in plant extracts by anthrone. Biochem. J. 57:508-514. https://doi .org/10.1042/bj0570508.

Yu, Q., X. Zhuang, S. Lv, M. He, Y. Zhang, Z. Yuan, W. Qi, Q. Wang, W. Wang, and X. Tan. 2013. Liquid hot water pretreatment of sugarcane bagasse and its comparison with chemical pretreatment methods for the sugar recovery and structural changes. Bioresour. Technol. 129:592-598. https://doi.org/10.1016/j.biortech.2012.11 .099 .

Yu, Q., X. Zhuang, W. Wang, W. Qi, Q. Wang, X. Tan, X. Kong, and Z. Yuan. 2016. Hemicellulose and lignin removal to improve the enzymatic digestibility and ethanol production. Biomass Bioenergy 94:105-109. https://doi.org/10.1016/j.biombioe.2016.08.005.

Yu, Q., X. Zhuang, Z. Yuan, Q. Wang, W. Qi, W. Wang, Y. Zhang, J. Xu, and H. Xu. 2010. Two-step liquid hot water treatment of Eucalyptus grandis to enhance sugar recovery and enzymatic digestibility of cellulose. Bioresour. Technol. 101:4895-4899. https:/ /doi.org/10.1016/j.biortech.2009.11.051.

Yu, Y., C. Lee, J. Kim, and S. Hwang. 2005. Group-specific primer and probe sets to detect methanogenic communities using quantitative real-time polymerase chain reaction. Biotechnol. Bioeng. 89:670-679. https://doi.org/10.1002/bit.20347.

Zhang, X., M. Wang, R. Wang, Z. Ma, D. Long, H. Mao, J. Wen, L. A. Bernard, K. A. Beauchemin, and Z. Tan. 2018. Urea plus nitrate treatment of rice and wheat straws enhances degradation and reduces methane production in in vitro ruminal culture. J. Sci. Food Agric. 98:5205-5211. https://doi.org/10.1002/jsfa.9056.

Zhao, S., G. Li, N. Zheng, J. Wang, and Z. Yu. 2018. Steam explosion enhances digestibility and fermentation of corn stover by facilitating ruminal microbial colonization. Bioresour. Technol. 253:244251. https://doi.org/10.1016/j.biortech.2018.01.024.

\section{ORCIDS}

Min Wang @ https://orcid.org/0000-0002-1113-7358

Karen A. Beauchemin ำ https://orcid.org/0000-0002-5070-4554

Bernard A. Lukuyu @ https://orcid.org/0000-0002-9374-3553 